\title{
Effects of Some Growth Promoting Substances on the Rate of Growth and Lactic Acid Production by Bifidobacterium bifidum in Sterilized Skim Milk
}

\author{
Abdelhamied, Eman A.; Dalia G. Kamel; Y.M. Abdelaziz and A.L. Hassan
}

Dairy Science Department, Faculty of Agriculture, Assiut University, Assiut, Egypt

Received on: 9/7/2019

Accepted for publication on: 30/7/2019

\begin{abstract}
Effect of some growth promoting substances, i.e., yeast extract, fructose, and peptone on the growth rate and acid production by Bifidobacterium bifidum in sterilized skim milk at $40^{\circ} \mathrm{C}$ was studied. Growth promoting substances were added to milk in three different concentrations, i.e., $0.1,0.3$, and $0.5 \%$. The obtained results indicated that the three substances resulted in an increased of growth and lactic acid production by Bifidobacterium bifidum. The maximum cell population in the presence of yeast extract reached were $25 \times 10^{4}, 12 \times 10^{5}$ and $21 \times 10^{5} \mathrm{CFU} / \mathrm{ml}$ after 12 hours. In the presence of $0.1,0.3$ and $0.5 \%$, respectively. The same effect was found in the presence of fructose and peptone, where the maximum cell population after 12 hours of incubation reached $35 \times 10^{4}, 46 \times 10^{4}$ and $53 \times 10^{4}$ and $25 \times 10^{4}, 51 \times 10^{4}$ and $40 \times 10^{5} \mathrm{CFU} / \mathrm{ml}$, respectively.

The obtained results showed a direct relationship between the rate of increase in C.F.U and DTA (developed titratable acidity).

Direct relationship could be established between the growth rate of Bifidobacterium bifidum in skim milk and the availability of utilizable nitrogenous compound, which might enhance the rate of growth. As it was expected, the highest population would reach in milk supplied with a good source of nitrogenous compounds such as peptone.
\end{abstract}

Keywords: Growth promoting, Bifidobacterium bifidum, Yeast Extract, Peptone, Fructose.

\section{Introduction}

Bifidobacteria are well known as a dominant bacteria found in the intestinal flora of a breastfed infant, and it has been known to provide many physiological properties to the human. Metchnikoff was one of the first to prove that soured milk containing bacteria may have positive effects on intestinal health (Cherie and Glenn, 1998).

Bifidobacterium was first isolated by Tissier (1900). In (2009 and 2012) Turroni et al., mentioned that Bifidobacterium bifidum is uniquely identified in the human gut and have been shown to represent part of the dominant bacterial members of the gut microbiota of the breastfed infants.

The cultivation of bifidobacteria in a medium like milk is a difficult task compared with that a conventional starter because milk is an artificial medium for growth of Bifidobacterium (Hadadji and Bensolture, 2006), and the conditions for cultivations must be strictly anaerobic. Also, they found that if growth promoting substance for bifidobacteria is added to the milk medium, bifidobacteria can be cultivated even in anaerobic conditions. 
Yeast extract, peptone, fructose, inulin, fructose oligosaccharides, and galacto-oligosaccharides can be used as growth promoting substances for Bifidobacteria, (Cheric and Glenn, 1998, Hadadji and Bensolture, (2006), Agil et al., (2013), Castro et al.,(2013a) and Castro et al., (2013b).

In 2003, Codex mentioned that a probiotic dairy product should contain at least $6.7 \log$ CFU g ${ }^{-1}$ of probiotic bacteria at the time of consumption and in quantity higher than $100 \mathrm{~g}$ per day in other words at least $9 \log$ CFU per day.

The present work aimed to compare the effect of some growth promoting substances, i.e., yeast extract, fructose, and peptone on the growth rate and acid production by Bifidobacterium bifidum in sterilized skim milk.

\section{Materials and Methods}

1- Milk:

Cow's milk used in this study was obtained from the herd of Faculty of Agriculture, Assiut University. As soon as milk arrived at the laboratory it was skimmed by using Alfa-Laval separator operated at $16000 \mathrm{rpm}$.

Skim milk was divided into 500 $\mathrm{ml}$ conical flasks, each flask contained from 150 - $300 \mathrm{ml}$ skim milk, depending on the experiment and the expected time for milk coagulation.

\section{2- Growth promoting substances:}

Three growth promoting substances, i.e., yeast extract, fructose, and peptone were added to conical flasks at three different concentrations, i.e., $0.1,0.3$ and $0.5 \%$, before by autoclaving at $121^{\circ} \mathrm{C} / 10$ minutes.

\section{3- Bifidobacterium bifidum}

Bifidobacterium bifidum was obtained from Microbiological Resources Centre (Cairo MIRCEN) Faculty of Agriculture Ain Shams University.

Bifidobacterium was routinely maintained in sterilized skimmed milk fortified with $0.1 \%$ yeast extract and stored at $5-7^{\circ} \mathrm{C}$.

For the preparation of the inocula, the procedure described by Hassan et al. (1989) was adopted. From each stored bacterial culture, $1 / 10$ dilutions were prepared in 250 $\mathrm{ml}$ conical flasks, each one contained from $150 \mathrm{ml}$ sterilized skim milk. After overnight of incubation at $40^{\circ} \mathrm{C}$, the first non-coagulated flask in which the bacteria were expected to be in the exponential phase of growth was used for inoculating the experimental flasks.

Inoculation was carried out in order to achieve $10^{3}$ to $10^{4} \mathrm{CFU} / \mathrm{ml}$ at the time of inoculation. Inoculated flasks were incubated anaerobically at $40^{\circ} \mathrm{C}$.

\section{4- Sampling:}

At the time of inoculation, (zero time) and each two hours intervals up to two hours after milk coagulation in most experiments or up to 48 hours, $15 \mathrm{ml}$ aliquots of each culture was aseptically withdrawn in $25 \mathrm{ml}$ sterilized conical flask.

$1 \mathrm{ml}$ of the aliquots was aseptically withdrawn in a test tube containing $9 \mathrm{ml}$ sterilized distilled water to give the first dilution $1 / 10$ for the bacteriological analysis $\left(10^{-1}\right)$, mixed gently for 30 seconds, and used for the preparation of the higher dilutions. 


\section{5- Bacteriological analysis:}

Enumeration of bacteria was carried out on TPY media. Petri dishes were incubated aerobically at $40^{\circ} \mathrm{C}$ for 5-7 days. Colonies were enumerated visually.

\section{6- Growth media:}

\section{- TPY media}

Selective medium for the isolation and cultivation of Bifidobacterium was obtained from (Laboratorios Conda S.A. Madrid Spain).

\section{7- Chemical analysis:}

Determination of Titratable Acidity:

Developed titratable acidity was determined according to the method as described in A.O.A.C., (2000) using sodium hydroxide N/9 and phenolphthalein as an indicator. Developed titratable acidity was expressed as the difference between the consumed volumes of $\mathrm{NaOH} N / 9$ solution in milliliter and volumes of $\mathrm{NaOH} N / 9$ consumed for the same titration of the above milk culture at the beginning of the incubation of cultures. The obtained results were recorded as a percent of lactic acid by weight as lactic acid.

Statistical analysis:

Stander deviation was determined according to Excel (2016).

\section{Results and Discussion}

The obtained results for the growth of Bifidobacterium bifidium in sterilized skim milk containing 0.1 , 0.3 , and $0.5 \%$ yeast extract at $40^{\circ} \mathrm{C}$ are presented in Table (1) and Figure (1). The maximum plate counts were $25 \times 10^{4}, 12 \times 10^{5}$ and $21 \times 10^{5} \mathrm{CFU} / \mathrm{ml}$, respectively, after 12 hours of incubation at $40^{\circ} \mathrm{C}$.

As it could be seen in Figure 1 that growth according to the rate of increase in colony forming units was steady at exponential rates up to 12 hours of incubation, and it clearly shows the effect of adding yeast extract to medium on the increase with the increase of added yeast extract.

Similar results were also obtained by Heap and Richardson (1985) and Ismail (1990), who detected higher CFU in reconstituted skim milk in the presence of $0.1 \%$ yeast extract.

The maximum CFU obtained in the presence of $0.5 \%$ yeast extract was $21 \times 10^{5} \mathrm{CFU} / \mathrm{ml}$, which is lower than that obtained by Yerlikay (2014), how detected a maximum CFU of $\times 10^{6}-10^{7} \mathrm{CFU} / \mathrm{ml}$.

On the other hand, our obtained results are in good agreement with those obtained by Mutai et al. (1978), who found that Bifidobacterium bifidum grew in milk containing yeast extract reached higher colony counts, compared with milk in the absence of yeast extract, and it was in correspondence with the concentration of added yeast extract.

The obtained results concerning the rate of increase of titratable acidity during the growth of Bifidobacteria bifidum in skim milk supplemented with yeast extract are presented in Table 4 and Figure 4. Direct relationship could be established between the growth rate and the corresponding culture acidity. The obtained results are comparable to those obtained by Mutai et al. (1978), who found a significant similarity 'between the number of viable bacteria and the acidity of the culture during cultivation.

Results presented in Table 2 and Figure 2 show the effect of adding 
fructose as growth promoting on the rate of growth of Bifidobacteria bifidum in sterilized skim milk at $40^{\circ} \mathrm{C}$. It could be seen that the addition of fructose greatly affected the growth rate of Bifidobacteria bifidum. The maximum population was $35 \times 10^{4}$, $46 \times 10^{4}$ and $53 \times 10^{4} \mathrm{CFU} / \mathrm{ml}$ after 12 hours in samples containing $0.1,0.3$ and $0.5 \%$ fructose, respectively. The obtained results came in agreement with those obtained by Mitsuka et al. (1987) and Hadadji and Bensoltane (2008), who indicated that the fructose resulted in a higher count of $\mathrm{Bi}$ fidobacteria bifidum, which confirm the effect of fructose as a growth promoting substance for these bacteria.

Rate of increase in DTA in cultures was proportional to the percentage of added fructose (Table 5 and Figure 5). The maximum population of Bifidobacteria bifidum was $35 \times 10^{4}, 46 \times 10^{4}$ and $53 \times 10^{4} \mathrm{CFU} / \mathrm{ml}$. The corresponding values for DTA were $0.36,0.38$ and $0.39 \%$ in the presence of $0.1,0.3$ and $0.5 \%$ fructose, respectively. These results agreed with the results obtained by Gibson et al. (1995), who found that in case of adding fructooligosaccharide to milk, lactic acid production in culture was proportional to the concentrate of the percentage of growth promoting.

Results in Table 3 and Figure 3 show the effect of adding peptone on the growth rate of Bifidobacteria bifidum which was greatly affected by concentration of added peptone, and the maximum population reached $25 \times 10^{4}, 51 \times 10^{4}$ and $40 \times 10^{5} \mathrm{CFU} / \mathrm{ml}$ after 12 hours of incubation with added $0.1,0.3$ and $0.5 \%$ peptone, respectively .

These results show direct relationship exist between the growth rate of Bifidobacteria bifidum in skim milk and the availability of utilizable nitrogenous compound which can enhance the rate of growth, and it was to be expected that it would reach the higher population in milk supplied with a good source of nitrogenous compounds such as peptone. The obtained results are slightly higher than those obtained by Wang and Gibson (1993) and Hadadji and Bensoltane (2006).

Table 6 and Figure 6 show the effect of adding peptone to skim milk on the production rate of lactic acid, which was increased as the percentage of added peptone was increased. In the same time, lactic acid production was proportional to the rate of increase in colony forming units.

After 12 hour of incubation the maximum cell population reached $25 \times 10^{4}, 51 \times 10^{4}$ and $40 \times 10^{5} \mathrm{CFU} / \mathrm{ml}$ in samples containing $0.1,0.3$ and $0.5 \%$ peptone, the corresponds values for DTA was $0.42,0.5$ and $0.50 \%$, respectively. Which indicate that mil, which was supplemented with $0.5 \%$ peptone was markedly superior to milk, contained less percentage of peptone 0.5 substrate for the rate of growth and acid production.

\section{Conclusion}

Concerning the results presented in Tables from 1 to 6 , at could be observed that yeast extract and peptone had a much higher effect as growth promoting substances for the growth of Bifidobacterium bifidum than fructose. Where the maximum CFU after 
12 hour of incubation reached $25 \times 10^{4}, 12 \times 10^{5}$ and $21 \times 10^{5} \mathrm{CFU} / \mathrm{ml}$ in samples with added $0.1,0.3$ and $0.5 \%$ yeast extract, the corresponding values for samples with peptone and fructose were $25 \times 10^{4}, 51 \times 10^{4}$ and $40 \times 10^{5}$ and $35 \times 10^{4}, 46 \times 10^{4}$ and $53 \times 10^{4} \mathrm{CFU} / \mathrm{ml}$, respectively.

Similar effect was found in the rate of increase in DTA corresponding to the rate of increase in colony forming units, which might prove the existence of direct relation between growth rate and rate of increase in DTA by Bifidobacterium bifidum.

These results indicated that a direct relationship might exist between the growth rate of Bifidobacteria bifidum in skim milk and the availability of utilizable nitrogenous compound which can enhance the rate of growth, and it was to be expected that it would reach the higher population in milk supplied with a good source of nitrogenous compounds such as peptone.

Table 1. Effect of adding yeast extract on growth rate (Log CFU/ml) of Bifidobacterium bifidum cultivated in sterilized skim milk at $40^{\circ} \mathrm{C}$.

\begin{tabular}{|c|c|c|c|c|c|c|}
\hline \multirow{3}{*}{$\begin{array}{c}\text { Sampling time } \\
\text { (hour) }\end{array}$} & \multicolumn{6}{|c|}{ Percentage of added yeast extract } \\
\cline { 2 - 7 } & $\mathbf{C F U} / \mathbf{m l}$ & $\begin{array}{c}\text { Log } \\
\text { CFU/ml }\end{array}$ & $\mathbf{C F U / m l}$ & $\begin{array}{c}\text { Log } \\
\text { CFU/ml }\end{array}$ & CFU/ml & $\begin{array}{c}\text { Log } \\
\text { CFU/ml }\end{array}$ \\
\hline & $10 \times 10^{4}$ & 5.00 & $15 \times 10^{4}$ & 5.17 & $30 \times 10^{4}$ & 5.47 \\
\hline 0 & $13 \times 10^{4}$ & 5.11 & $32 \times 10^{4}$ & 5.50 & $64 \times 10^{4}$ & 5.80 \\
\hline 2 & $16 \times 10^{4}$ & 5.20 & $55 \times 10^{4}$ & 5.74 & $11 \times 10^{5}$ & 6.04 \\
\hline 4 & $20 \times 10^{4}$ & 5.30 & $80 \times 10^{4}$ & 5.90 & $16 \times 10^{5}$ & 6.20 \\
\hline 6 & $23 \times 10^{4}$ & 5.36 & $99 \times 10^{4}$ & 5.99 & $19 \times 10^{5}$ & 6.27 \\
\hline 8 & $24 \times 10^{4}$ & 5.38 & $11 \times 10^{5}$ & $6.0 \leqslant$ & $20 \times 10^{5}$ & 6.30 \\
\hline 10 & $25 \times 10^{4}$ & 5.40 & $12 \times 10^{5}$ & 6.08 & $21 \times 10^{5}$ & $6.31^{*}$ \\
\hline 12 & $83 \times 10^{4}$ & 5.91 & $13 \times 10^{5}$ & $6.11^{*}$ & $17 \times 10^{5}$ & 6.23 \\
\hline 24 & $70 \times 10^{4}$ & $5.84 *$ & $10 \times 10^{5}$ & 6.00 & $14 \times 10^{5}$ & 6.15 \\
\hline 26 & & 0.30 & & 0.31 & 0.28 & \\
\hline SD & & & & & & \\
\hline
\end{tabular}

*Coagulated sample.

Table 2. Influence of adding fructose on the growth rate $(\mathrm{Log} \mathrm{CFU} / \mathrm{ml})$ of Bifidobacterium bifidum cultivated in sterilized skim milk at $40^{\circ} \mathrm{C}$.

\begin{tabular}{|c|c|c|c|c|c|c|}
\hline \multirow{2}{*}{$\begin{array}{c}\text { Sampling } \\
\text { time } \\
\text { (hour) }\end{array}$} & \multicolumn{7}{|c|}{\begin{tabular}{c} 
Porcentage of added fructose \\
\cline { 2 - 7 }
\end{tabular}} & $\mathbf{C F U / m l}$ & $\begin{array}{c}\text { Log } \\
\text { CFU/ml }\end{array}$ & CFU/ml & $\begin{array}{c}\text { Log } \\
\text { CFU/ml }\end{array}$ & CFU/ml & $\begin{array}{c}\text { Log } \\
\text { CFU/ml }\end{array}$ \\
\hline 0 & $5 \times 10^{4}$ & 4.69 & $8 \times 10^{4}$ & 4.90 & $10 \times 10^{4}$ & 5.00 \\
\hline 2 & $8 \times 10^{4}$ & 4.90 & $13 \times 10^{4}$ & 5.10 & $16 \times 10^{4}$ & 5.20 \\
\hline 4 & $12 \times 10^{4}$ & 5.08 & $19 \times 10^{4}$ & 5.27 & $24 \times 10^{4}$ & 5.38 \\
\hline 6 & $17 \times 10^{4}$ & 5.23 & $27 \times 10^{4}$ & 5.43 & $33 \times 10^{4}$ & 5.51 \\
\hline 8 & $22 \times 10^{4}$ & 5.34 & $34 \times 10^{4}$ & 5.53 & $40 \times 10^{4}$ & 5.60 \\
\hline 10 & $28 \times 10^{4}$ & 5.45 & $41 \times 10^{4}$ & 5.61 & $47 \times 10^{4}$ & 5.67 \\
\hline 12 & $35 \times 10^{4}$ & 5.54 & $46 \times 10^{4}$ & 5.66 & $53 \times 10^{4}$ & 5.72 \\
\hline 24 & $40 \times 10^{4}$ & 5.60 & $51 \times 10^{4}$ & 5.70 & $58 \times 10^{4}$ & 5.76 \\
\hline 26 & $45 \times 10^{4}$ & 5.65 & $55 \times 10^{4}$ & 5.74 & $61 \times 10^{4}$ & 5.78 \\
\hline SD & & 0.33 & & 0.29 & & 0.27 \\
\hline
\end{tabular}


Table 3. Effect of adding peptone on the growth rate $(\log \mathrm{CFU} / \mathrm{ml})$ of Bifidobacterium bifidum cultivated in sterilized skim milk at $40^{\circ} \mathrm{C}$

\begin{tabular}{|c|c|c|c|c|c|c|}
\hline \multirow{3}{*}{$\begin{array}{l}\text { Sampling time } \\
\text { (hour) }\end{array}$} & \multicolumn{6}{|c|}{ Percentage of added peptone } \\
\hline & \multicolumn{2}{|c|}{0.1} & \multicolumn{2}{|c|}{0.3} & \multicolumn{2}{|c|}{0.5} \\
\hline & $\mathrm{CFU} / \mathrm{ml}$ & $\begin{array}{c}\text { Log } \\
\text { CFU/ml }\end{array}$ & $\mathrm{CFU} / \mathrm{ml}$ & $\begin{array}{c}\text { Log } \\
\text { CFU/ml }\end{array}$ & $\mathrm{CFU} / \mathrm{ml}$ & $\begin{array}{c}\text { Log } \\
\text { CFU/ml }\end{array}$ \\
\hline 0 & $70 \times 10^{3}$ & 4.84 & $72 \times 10^{3}$ & 4.85 & $25 \times 10^{4}$ & 5.40 \\
\hline 2 & $82 \times 10^{3}$ & 4.91 & $10 \times 10^{4}$ & 5.00 & $30 \times 10^{4}$ & 5.48 \\
\hline 4 & $10 \times 10^{4}$ & 5.00 & $16 \times 10^{4}$ & 5.20 & $40 \times 10^{4}$ & 5.60 \\
\hline 6 & $13 \times 10^{4}$ & 5.11 & $25 \times 10^{4}$ & 5.39 & $50 \times 10^{4}$ & 5.69 \\
\hline 8 & $16 \times 10^{4}$ & 5.20 & $35 \times 10^{4}$ & 5.54 & $64 \times 10^{4}$ & 5.80 \\
\hline 10 & $20 \times 10^{4}$ & 5.30 & $44 \times 10^{4}$ & 5.64 & $80 \times 10^{4}$ & 5.90 \\
\hline 12 & $25 \times 10^{4}$ & 5.40 & $51 \times 10^{4}$ & 5.70 & $40 \times 10^{5}$ & 6.60 \\
\hline 24 & $10 \times 10^{5}$ & $6.00^{*}$ & $13 \times 10^{5}$ & 6.11 & $16 \times 10^{6}$ & 7.20 \\
\hline SD & & 0.37 & & 0.40 & & 0.62 \\
\hline & & & & & & \\
\hline & & & & & & \\
\hline
\end{tabular}

* coagulated sample

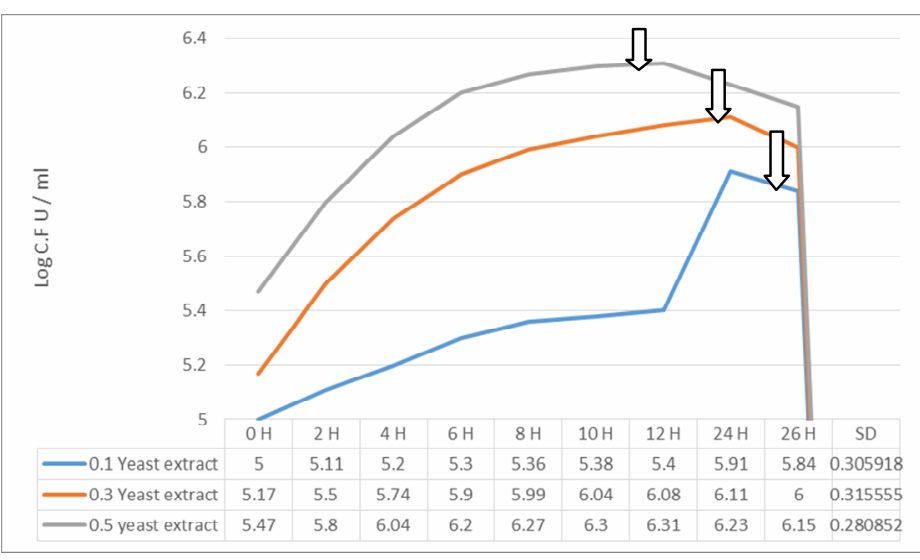

Figure 1: Effect of adding yeast extract on growth rate $(\log \mathrm{CFU} / \mathrm{ml})$ of Bifidobacterium bifidum cultivated in sterilized skim milk at $40^{\circ} \mathrm{C}$.

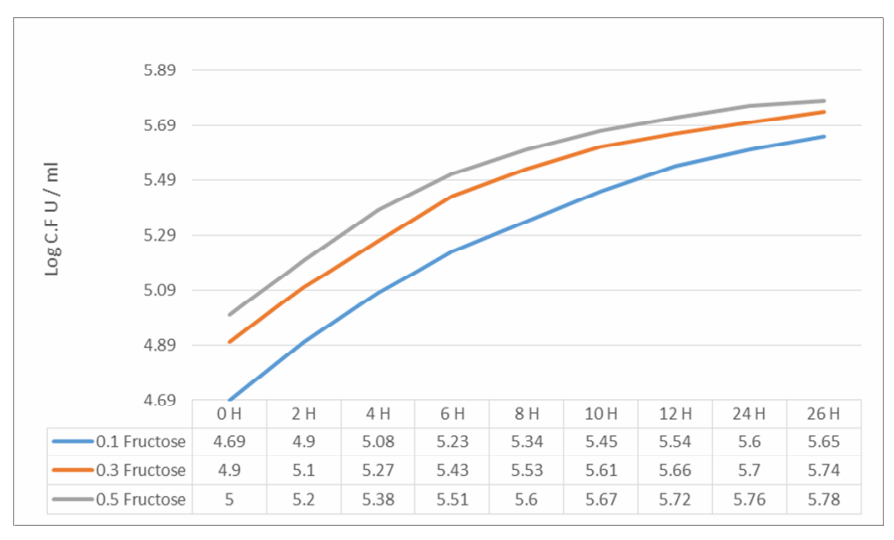

Figure 2: Effect of adding fructose on the growth rate (log $\mathrm{CFU} / \mathrm{ml}$ ) of Bifidobacterium bifidum cultivated in sterilized skim milk at $40^{\circ} \mathrm{C}$.

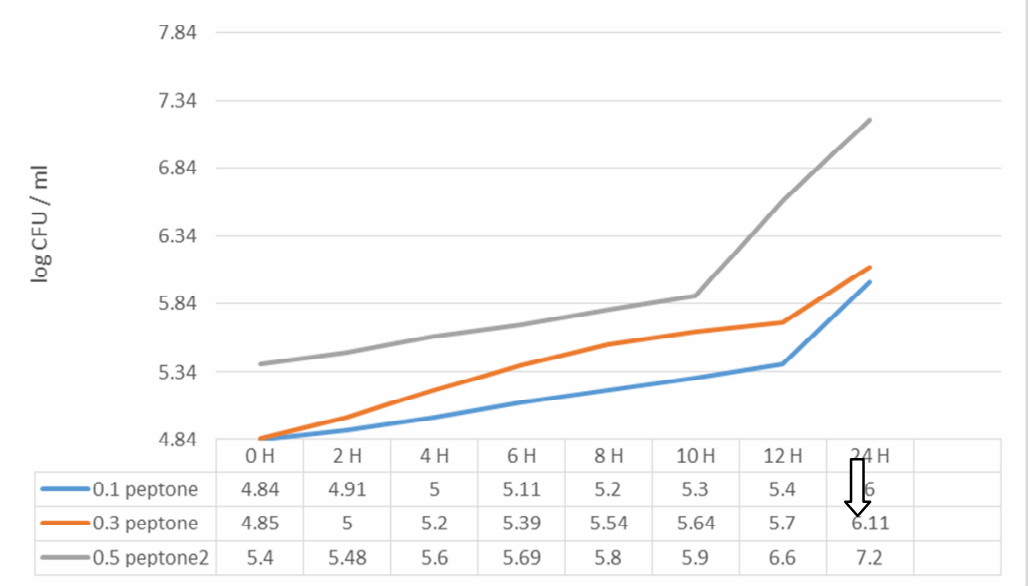

Figure 3: Effect of adding peptone on the growth rate (log CFU / $\mathrm{ml}$ ) of Bifidobacterium bifidum cultivated in sterilized skim milk at $40^{\circ} \mathrm{C}$. 
Table 4. Effect of adding yeast extract on the rate of increase in D.T.A (\%) during the growth of Bifidobacterium bifidum cultivated in sterilized skim milk at $40^{\circ} \mathrm{C}$.

\begin{tabular}{|c|c|c|c|c|c|c|}
\hline \multirow{2}{*}{$\begin{array}{c}\text { Sampling } \\
\text { time (hour) }\end{array}$} & \multicolumn{7}{|c|}{ Percentage of added yeast extract } \\
\cline { 2 - 7 } & \%DTA & $\begin{array}{c}\text { Difference } \\
\text { in DTA }\end{array}$ & \%DTA & $\begin{array}{c}\text { Difference } \\
\text { in DTA }\end{array}$ & \%DTA & $\begin{array}{c}\text { Difference } \\
\text { in DTA }\end{array}$ \\
\hline 0 & 0.25 & 0.00 & 0.26 & 0.00 & 0.27 & 0.00 \\
\hline 2 & 0.27 & 0.02 & 0.28 & 0.02 & 0.29 & 0.02 \\
\hline 4 & 0.28 & 0.03 & 0.29 & 0.03 & 0.30 & 0.03 \\
\hline 6 & 0.29 & 0.04 & 0.30 & 0.04 & 0.31 & 0.04 \\
\hline 8 & 0.35 & 0.10 & 0.37 & 0.11 & 0.40 & 0.13 \\
\hline 10 & 0.40 & 0.15 & 0.43 & 0.17 & 0.44 & 0.17 \\
\hline 12 & 0.44 & 0.19 & 0.45 & 0.19 & $0.49^{*}$ & 0.22 \\
\hline 24 & $0.70^{*}$ & 0.45 & $0.72 *$ & 0.46 & $0.73^{*}$ & 0.46 \\
\hline 26 & 0.71 & 0.46 & 0.73 & 0.47 & 0.74 & 0.47 \\
\hline
\end{tabular}

*Coagulated sample.

Table 5. Effect of adding fructose on increasing rate in D.T.A (\%) during the growth of Bidobacterium bifidum cultivated in sterilized skim milk at $40^{\circ} \mathrm{C}$.

\begin{tabular}{|c|c|c|c|c|c|c|}
\hline \multirow{2}{*}{$\begin{array}{c}\text { Sampling } \\
\text { time (hour ) }\end{array}$} & \multicolumn{7}{|c|}{ Percentage of added fructose } \\
\cline { 2 - 7 } & \%DTA & $\begin{array}{c}\text { Difference } \\
\text { in DTA }\end{array}$ & \%DTA & $\begin{array}{c}\text { Difference } \\
\text { in DTA }\end{array}$ & \%DTA & $\begin{array}{c}\text { Difference } \\
\text { in DTA }\end{array}$ \\
\hline 0 & 0.26 & 0.00 & 0.27 & 0.00 & 0.28 & 0.00 \\
\hline 2 & 0.27 & 0.01 & 0.29 & 0.02 & 0.30 & 0.02 \\
\hline 4 & 0.28 & 0.02 & 0.31 & 0.04 & 0.32 & 0.04 \\
\hline 6 & 0.30 & 0.04 & 0.32 & 0.05 & 0.33 & 0.05 \\
\hline 8 & 0.32 & 0.06 & 0.33 & 0.06 & 0.34 & 0.06 \\
\hline 10 & 0.34 & 0.08 & 0.35 & 0.08 & 0.36 & 0.08 \\
\hline 12 & 0.36 & 0.10 & 0.38 & 0.11 & 0.39 & 0.11 \\
\hline 24 & 0.42 & 0.16 & 0.44 & 0.17 & $0.46^{*}$ & 0.18 \\
\hline 26 & 0.43 & 0.17 & $0.45^{*}$ & 0.18 & 0.46 & 0.18 \\
\hline
\end{tabular}


Table 6. Effect of adding peptone on the increasing rate in D.T.A (\%) during the growth of Bidobacterium bifidum cultivated in sterilized skim milk at $40^{\circ} \mathrm{C}$.

\begin{tabular}{|c|c|c|c|c|c|c|}
\hline \multicolumn{7}{|c|}{ Percentage of added peptone } \\
\hline $\begin{array}{c}\text { Sampling } \\
\text { time (hour) }\end{array}$ & \%DTA & $\begin{array}{c}\text { Difference } \\
\text { in DTA }\end{array}$ & \%DTA & $\begin{array}{c}\text { Difference } \\
\text { in DTA }\end{array}$ & \%DTA & $\begin{array}{c}\text { Difference } \\
\text { in DTA }\end{array}$ \\
\hline 0 & 0.27 & 0.00 & 0.28 & 0.00 & 0.29 & 0.00 \\
\hline 2 & 0.29 & 0.02 & 0.30 & 0.02 & 0.31 & 0.02 \\
\hline 4 & 0.30 & 0.03 & 0.32 & 0.04 & 0.33 & 0.04 \\
\hline 6 & 0.31 & 0.04 & 0.34 & 0.06 & 0.35 & 0.06 \\
\hline 8 & 0.34 & 0.07 & 0.36 & 0.08 & 0.37 & 0.08 \\
\hline 10 & 0.37 & 0.10 & 0.43 & 0.15 & 0.44 & 0.15 \\
\hline 12 & 0.42 & 0.15 & $0.50^{*}$ & 0.22 & $0.50^{*}$ & 0.21 \\
\hline 24 & $0.72^{*}$ & 0.45 & $0.77^{*}$ & 0.49 & $0.79^{*}$ & 0.50 \\
\hline 26 & 0.72 & 0.45 & 0.77 & 0.49 & 0.79 & 0.50 \\
\hline
\end{tabular}

*coagulated sample

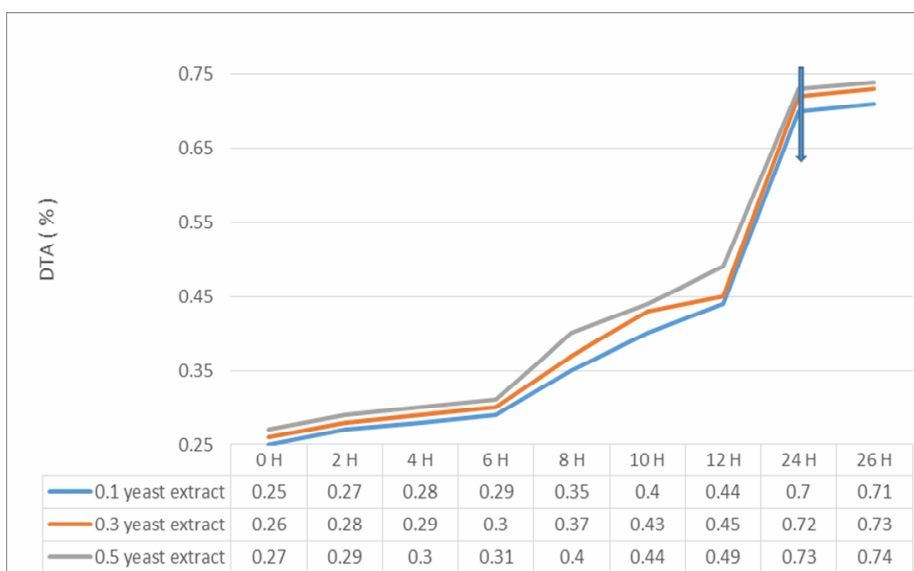

Figure 4: Effect of adding yeast extract on increasing rate in D.T.A (\%) during growth of Bidobacterium bifidum cultivated in sterilized skim milk at $40^{\circ} \mathrm{C}$

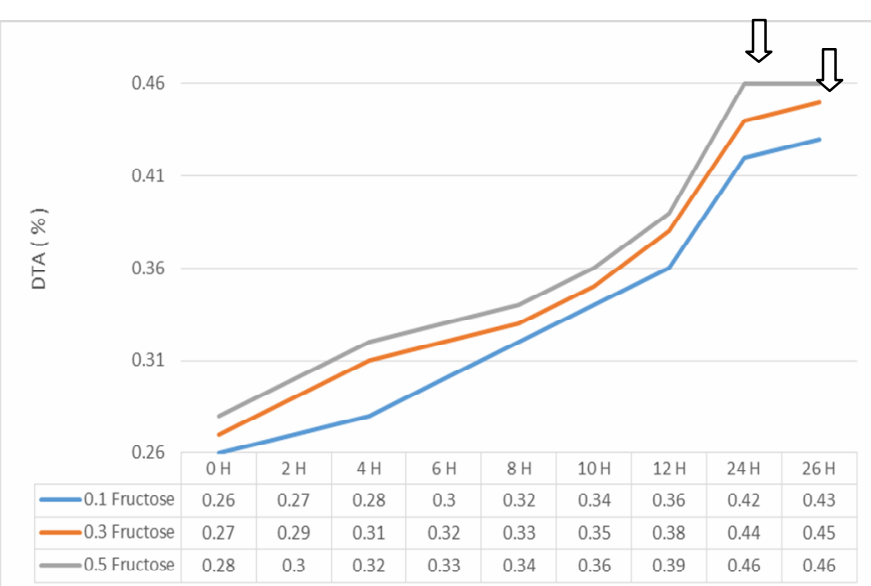

Figure 5: Effect of adding fructose on increasing rate in D.T.A (\%) during growth of Bidobacterium bifidum cultivated in sterilized skim milk at $40^{\circ} \mathrm{C}$

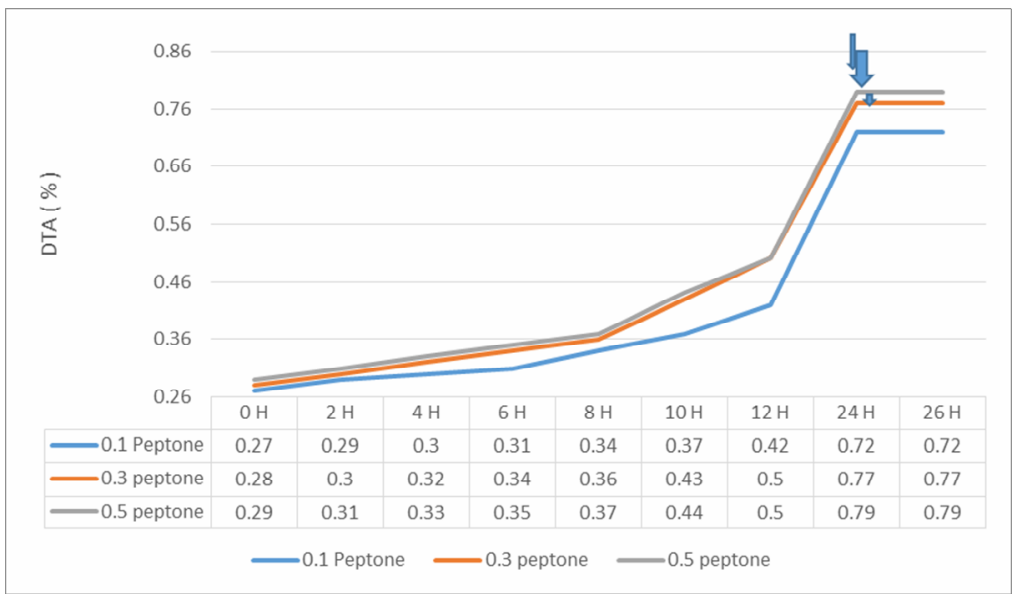

Figure 6: Effect of adding peptone on increasing rate in D.T.A (\%) during growth of Bidobacterium bifidum cultivated in sterilized skim milk at $40^{\circ} \mathrm{C}$. 


\section{Reference:}

Agil, R., A., Gliwa, J., Avis, T.Y., Willmore, W.G., and Hosseinian, F. (2013). Lentil enhance probiotic growth in yoghurt and provide added benefit of antioxidant protection. LWT - Food science and Technology, 50 (1): $45-44$.

A.O.A.C. (2000). Association of Official Analytical Chemists Official Method of analysis, Association of official Agriculture Chemists, $17^{\text {th }}$ ed Wisconsin: Georgea Banta CO. Inc.

Castro, W.F., A.G., Bisinotto, M.S., Guerreiro, L.M., Faria, J.A., Bolini, H.M., Cunha R.L. and Deliza, R (2013a). Development of probiotic dairy beverage: rheological properties and application of mathematical models in sensory evaluation. Journal of Dairy Science, $96: 16-25$.

Castro, W.F., Cruz, A.G., Rodrigues, O., Ghiselli, G., oliveira, C.A., Faria, J.A. and Godoy, H.T. (2013b). Short communication: effects of different whey concentration on physiochemical characteristics and viable counts of starter bacteria in dairy beverage supplemented with probiotics. Journal of dairy science, 96: $96-100$.

Cherie, J. Ziemer and Glenn R.G. (1998). An overview of probiotics, prebiotics and synbiotics in the functional food concept: perspectives and future strategies Int. Dairy Journal. 8: 473 - 479.

Codex, (2003). Codex Stan 243 - 2003: Codex standard for fermented milk. Rome: Codex Alimentarius commission.

Gibson. G.R., Beatty, E.R., Wanyx, Cummings Jif. (1995). Selective stimulation of Bifidobacteria in the human colony by oligofructose and inulin. Amer; Gastrocnt. Assoc. 108: $975-982$.
Hadadji, M. and Bensoltane A. (2006). Growth and lactic acid production by Bifidobacteriumlongum and Lactobacillus acidophilus in goats milk. African Journal of Biotechnology. 5(6): $505-509$.

Hassan, A.1., Deschamps and J. Richard (1989). Precision des measure de vitesse de croissance de Streptococcus Lactiguesdans le lait basses surlamethed de denombrementmicrobium par formation de colonies: Etude de reference avicLactococcusLactis le Lait, 69: 433 447.

Heap, H.A. and G.H. Richardson (1985). The proteolytic effect of fast coagulating and low coagulating strain of Streptococcus cremoris. N.Z.J. Dairy sci., Technol., 20: 156 -165 .

Ismail, A. (1990). Effect of medium on the growth rate of slow and fast acid production variants of Lactococcus lactis. Assiut J. Agric. Sci., 21(93-109).

Mitsuka, T., Hidaka H. and Eida T. (1987). Effect of fructoolegosaccharides on intestinal microflora. Die. Nahrung 37: 427 - 436.

Mutai, M., Mada, M., Nakajina, F., Murayama, H., Shimada, K. and Lijima, T. (1978). Fermented milk product containg viable Bifidobacteria. U.S. patent Document 11 (1969).

Tissier, (1990). Recherchers Sur La Flora Intestinale Normale et Pathologique Du Nourisson. Ph.D. thesis, University of Paris, Paris.

Turroni, F., Foroni, E., Pizzetti, P., Giubellini, V., Ribbera, A., Merusi, P., et al. (2009). Exploring the diversity of bifidobacterial population in the human intestinal tract.Appl.Environ.Microbial.75,1 534-1545.doi:10.1128/AEM.02216 $-08$. 
Turroni, F., Peano, C., Pass, D.A., Foroni, E., Severgnini, M., Claesson, M.j., et al.(2012). Diversity of bifidobacteria within the infant gut microbiota. PLoS ONE 7:e36957. doi:10.1371/journal.pone.0036957.

Wang, X. and Gibson G.R. (1993). Effects of the inviter termination of oligofructose and inulin by bacte- ria growing in human large intestine. J. Appl. Bacterial 75: 373 38.

Yerlikaya, O. (2014). Starter cultures used in probiotic dairy product preparation and popular probiotic dairy products. Food Scie. Technol. Campinas, 34 (2): 221 - 229. 


\section{تاثير بعض العوامل المحفزة للنمو علي معدل نمو وانتاج الحموضة لبكتريا Bifidobacterium bifidum \\ ايمان عبد الحميد ، داليا جمال كامل ، ياسر عبد العزيز وعلى اسماعيل حسن \\ قسم الألبان - كلية الزر اعة - جامعة أسيوط}

لقد تمت در اسة بعض العو امل المحفزة للنمو منل مستخلص الخميرة و الفركتوز و البيتون علي معدل نمو بكتريا Bifidobacterium bifidum و انتاجها للحموضة في اللبن الفرز المعقم.

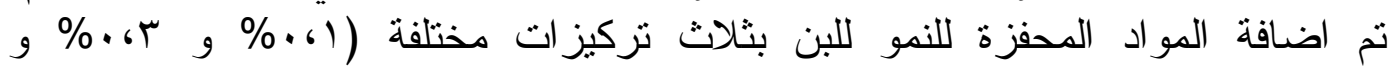
. $(\%$. 60

وقد وجد ان هذه المو اد أدت الي زيادة معدل النمو لبكتريا Bifidobacterium bifidum

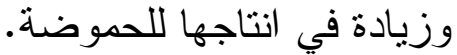
وتم الحصول علي النتائج التالية:

في العينات التي تحتوي علي مستخلص الخميرة كانت القيمة القصوي التي تم الحصول

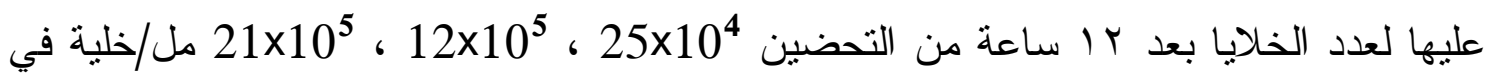

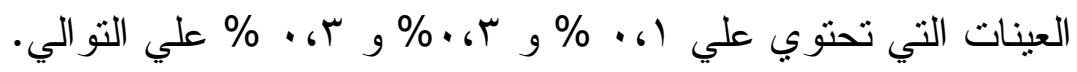

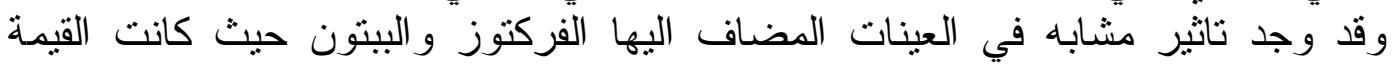

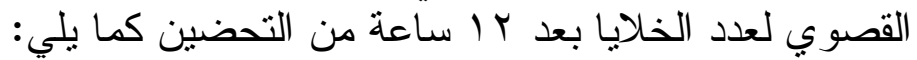
35x104

$$
\text { 25x104 }
$$

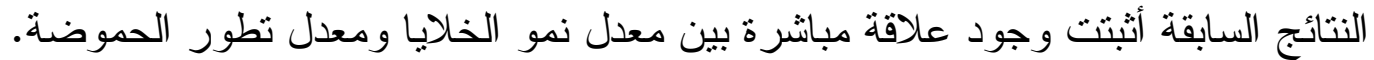

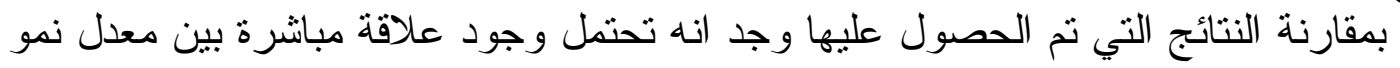
بكتريا Bifidobacterium bifidum في اللبن الفرز و المركبات النيتزوجينة المتاحة التي تم تمدي

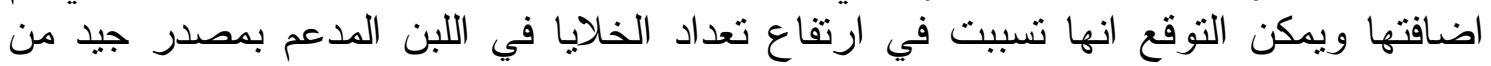
المركبات النيتروجينية مثل البيتون. 